\title{
Currency Substitution and Financial Repression
}

\author{
Rangan Gupta*
}

\begin{abstract}
In this paper, we use a general equilibrium overlapping generations monetary endogenous growth model of a small open economy, to analyze whether financial repression, measured via the "high" mandatory reserve-deposit requirements of financial intermediaries, is an optimal response of a consolidated government following an increase in the degree of currency substitution. We find that higher currency substitution can yield higher reserve requirements, but, the result depends crucially on how the consumer weighs money in the utility function relative to domestic and foreign consumptions, and also the size of the government.
\end{abstract}

Journal of Economic Literature Classification: E31; E44; E63; F43.

Keywords: Currency Substitution; Endogenous Growth Models; Financial Repression; Small Open Economy; Public Finance.

${ }^{*}$ Contact details: Professor, Department of Economics, University of Pretoria, Pretoria, 0002, South Africa, Email: Rangan.Gupta@up.ac.za. Phone: +27 12420 3460. I would like to thank an anonymous referee for many helpful comments. 


\section{Introduction}

Using a general equilibrium overlapping generations monetary endogenous growth model of small open economy, we analyze the relationship between currency substitution and financial repression. We follow Drazen (1989), Bacchetta and Caminal (1992), Haslag and Hein (1995), Espinosa and Yip (1996), Haslag (1998), Haslag and Koo (1999), Haslag and Bhattacharya (2001), Gupta (2005, 2006, 2008) and Gupta and Ziramba (2008a,b, 2009a,b) amongst others, in defining financial repression through an obligatory "high" reserve deposit ratio requirement, that the banks in the economy needs to maintain. In other words, the study attempts to assay whether there exists a plausible explanation as to why the reserve requirements in some economies are higher than others. Specifically, we analyze whether the "high" reserve requirements in a small open economy characterized by currency substitution, are a fall out of a welfare maximizing decision of the government, having access to income taxation and seigniorage as sources of revenue.

The motivation for believing that currency substitution can be a possible rationale for financial repression, can be outlined as follows: In a small open economy, inflation often leads to currency substitution, which, in turn, tends produce a negative impact on the revenue raised by the government via seigniorage. In such a back drop, our paper analyzes whether increasing the reserve requirements, our metric for financial repression, could be identified as an welfare-maximizing response of the government. This is simply because, the increase in reserve requirements would tend to recuperate the fall in the size of the seigniorage base, that results from substitution of the domestic currency.

Note, financial repression can be broadly defined as a set of government legal restrictions, like interest rate ceilings, compulsory credit allocation and high reserve requirements, that generally prevent the financial intermediaries from functioning at their full capacity level. However, given the wave of interest rate deregulation in the 1980s, and removal credit ceiling some years earlier, the major form of financial repression is currently via obligatory reserve requirements. ${ }^{1}$ As Espinosa and Yip (1996) points out, the concern is not whether financial repression is prevelent, but the associated degree to which an economy is repressed, since developed or developing economies both resort to such restrictive policies.

Now the pertinent question here is - Why, if at all, would a government want to repress the financial

\footnotetext{
${ }^{1}$ See Caprio et al. (2001) for further details.
} 
system? This seems paradoxical, especially when one takes into account the well documented importance of the financial intermediation process on economic activity, mainly via the finance-growth nexus. ${ }^{2}$ Besides, the fact that "high" cash reserve requirements enhances the size of the implicit tax base and, hence, is lucrative for the government to repress the financial system, alternative explanations, with varied success, have ranged from inefficient tax systems, in the form of tax evasion (Cukierman et al.,1992; Giovannini and De Melo, 1993; Roubini and Sala-i-Martin, 1995; Gupta (2005, 2006, 2008) and Gupta and Ziramba (2009a)) and cost of tax collection (Gupta and Ziramba, 2008a, 2009b), to degree of financial development (Di Giorgio, 1999) to imperfect information and the possibility of banking crisis (Gupta, 2005; 2006) and finally to bureaucratic corruption (Gupta and Ziramba, 2008b). However, to the best of our knowledge, this is the first study to use currency substitution as a rationale for financial repression. Overall, from a public finance perspective, our study can also be viewed as analyzing optimal policy decisions, involving direct and implicit taxation, within a small open economy as the degree of currency substitution changes.

In this regard, it is important to highlight a related recent paper by Holman and Neanidis (2006). These authors, studied the growth and welfare effects of income tax and seigniorage in a small open economy characterized by currency substitution and and tax evasion. The paper indicates that seigniorage finance has stronger negative effects on growth relative to income taxation, when countries have less-developed financial markets. This result is reinforced fr economies with higher degree of currency substitution, greater substitutability of domestic currency via foreign currency and limited tax evasion. Finally, income taxation is found to be the least distortionary method of financing a given amount of government expenditures. Our study draws from this framework and analyzes the effect of an increase in the degree of currency substitution on financial repression in a welfare maximizing set up, with financial restriction being measured via the size of mandatory reserve requirements that the banks in the economy needs to hold. Note, in the process, we have now allowed for an additional policy instrument, namely the reserve requirement, beside the income tax rate and the money growth rate, as used in their study. Besides modeling financial repression this way and trying to relate it to currency substitution, the decision to include cash-reserve ratio in the model is also data motivated. Based on the International Financial Statistics of the IMF, the average reserve requirement

\footnotetext{
${ }^{2}$ See Roubini and Sala-i-Martin (1992), and the references cited there in.
} 
for the 22 economies considered by Holman and Neanidis (2006) was found to be 22.02 percent over the period of 1980 to 2006 . Clearly, then ratio was quite substantial, and cannot be ignored as a monetary policy instrument.

Note, our results are difficult to compare directly with those of Holman and Neanidis (2006), not only because we are asking a different question, but also due to the fact that in our case the key monetary policy instrument measuring the degree of financial repression, namely the reserve requirement, is endogenous, unlike an exogenous measure of financial sector development used by Holman and Neanidis (2006). In addition, as will be seen below, currency substitution does not affect growth in our model and our constrained welfare maximization problem studies how the policy instruments would behave as the degree of currency substitution changes. Besides, our measure of welfare is quite different from that of Holman and Neanidis (2006) and in our case money is introduced via the money-in-the-utility (MIU) model rather than the cashin-advance (CIA) constraint used by these authors. The remainder of the paper is organized as follows: Section 2 outlines the economic environment and Section 3 defines the equilibrium. Section 4 derives the conditions under which financial repression and currency substitution tends to be positively related as part of a welfare-maximizing outcome, while, Section 5 concludes and lays out the areas of further research.

\section{Economic Environment}

In this section, the overlapping generations model of Diamond (1965) is modified to depict a financially repressed structure of a small open economy, characterized by currency substitution. The economy is populated by four types of agents, namely, consumers, banks (financial intermediaries), firms and an infinitely-lived government. The following subsections lays out the economic environment in detail, by considering each of the agents separately and accounting for the external sector.

\subsection{Consumers}

The economy is characterized by an infinite sequence of two-period- lived overlapping generations of consumers. Time is discrete and is indexed by $t=1,2, \ldots$ At each date $t$, there are two coexisting generations 
- young and old. $N$ people are born at each time point $t \geq 1$. At $t=1$, there exist $N$ people in the economy, called the initial old, who live for only one period. Hereafter $N$ is normalized to 1 .

Each agent is endowed with one unit of working time $\left(n_{t}\right)$ when young and is retired when old. The agent supplies this one unit of labor inelastically and receives a competitively determined real wage of $w_{t}$. We assume that the agents consume only when old ${ }^{3}$ and, hence, the net of tax wage earnings are allocated between bank deposits and domestic and foreign currencies. Money is held by the consumer because it gives utility. The proceeds from the bank deposits are used to obtain second period consumption. The consumption bundle comprises of a domestically produced good and an imported foreign good. We assume a separable and additive log-utility function in the two goods and composite money. A notable feature of our model is the lack of bonds of any type, either domestic or foreign. In a world of no uncertainty, incorporating bonds in either the consumer portfolio or the bank problem, the latter described in Subsection 2.2, would imply multiplicity of optimal allocations of deposits (or loans) and bonds, since the "no arbitrage" conditions would imply a relative price of one between deposits (or loans) with domestic and foreign bonds.

Formally, the agents problem born in period $t$ is as follows:

$$
\begin{aligned}
U\left(c_{t+1}, c_{t+1}^{*}, m_{1 t}, f_{t}\right) & =\psi_{1} \log c_{t+1}+\psi_{2} \log c_{t+1}^{*}+\left(1-\psi_{1}-\psi_{2}\right) \log \left[m_{1 t}^{\lambda} f_{t}^{*(1-\lambda)}\right] \\
p_{t} d_{t}+p_{t} m_{1 t}+\left[e_{t} p_{t}^{*}\right] f_{t}^{*} & \leq\left(1-\tau_{t}\right) p_{t} w_{t} \\
p_{t+1} c_{t+1}+\left[e_{t+1} p_{t+1}^{*}\right] c_{t+1}^{*} & \leq\left[1+i_{d t+1}\right] p_{t} d_{t}+p_{t} m_{1 t}+\left[e_{t} p_{t}^{*}\right] f_{t}^{*}
\end{aligned}
$$

where $U(\cdot)$ is the utility function, with the standard assumptions of positive and diminishing marginal utilities in both goods and both currencies; $\psi_{1}, \psi_{2}$ and $\left[1-\psi_{1}-\psi_{2}\right]$ are the weights the consumer assigns to the domestic and foreign goods and the composite money in the utility function; $c_{t+1}$ and $c_{t+1}^{*}$ are the old age consumption of domestic and foreign goods, respectively; $m_{1 t}$ and $f_{t}^{*}$ and $d_{t}$ indicates, in real terms, the consumer's holding of the the domestic and foreign currencies and deposits, respectively; $\lambda(1-\lambda)$ with $0<$ $\lambda<1$, captures the weight of domestic (foreign) currency in composite money; $\tau_{t}$ is the tax rate at period $t$; $w_{t}$ is the real wage rate; $p_{t}\left(p_{t}^{*}\right)$, is the domestic (foreign) price at period $t ; e_{t}$ is the nominal exchange rate;

\footnotetext{
${ }^{3}$ This assumption has no bearing on the results of our model. It makes computations easier and also seems to be a good approximation of the reality. For details see Hall (1988).
} 
and, $i_{d t+1}$ is the nominal interest rate on bank deposits.

The maximization problem of the consumer yields the following optimal choices:

$$
\begin{aligned}
c_{t+1} & =\psi_{1}\left[\frac{1+i_{d t+1}}{1+\pi_{t+1}}\right]\left(1-\tau_{t}\right) w_{t} \\
c_{t+1}^{*} & =\psi_{2}\left[\frac{1+i_{d t+1}}{1+\pi_{t+1}}\right]\left(1-\tau_{t}\right) w_{t} \\
m_{1 t} & =\left(1-\psi_{1}-\psi_{2}\right)\left[\frac{1+i_{d t+1}}{i_{d t+1}}\right] \lambda\left(1-\tau_{t}\right) w_{t} \\
f_{t}^{*} & =\left(1-\psi_{1}-\psi_{2}\right)\left[\frac{1+i_{d t+1}}{i_{d t+1}}\right](1-\lambda)\left(1-\tau_{t}\right) w_{t} \\
d_{t} & =\frac{\left[\left(\psi_{1}+\psi_{2}\right)\left(1+i_{d t+1}\right)-1\right]}{i_{d t+1}}\left(1-\tau_{t}\right) w_{t}
\end{aligned}
$$

We assume that the Purchasing Power Parity (PPP) condition, $p=e p^{*}$ holds. Since $p^{*}$ is parametrically given to the small-open economy, we set it to unity without any loss of generality. Hence, implying that the domestic price level and the nominal exchange rates are synonymous for the model economy, with the PPP condition being satisfied, i.e., $p_{t}=e_{t}$. Note $\frac{p_{t+1}}{p_{t}}=\frac{p_{t+1}}{p_{t}}=1+\pi_{t+1}$.

\subsection{Financial Intermediaries}

At the start of each period, the financial intermediaries accept deposits and make their portfolio decision i.e., loans and cash reserves choices, with a goal of maximizing profits. At the end of the period, they receive their interest income from the loans made and meets the interest obligations on the deposits. Note the intermediaries are constrained by legal requirements on the choice of their portfolio (i.e., reserve requirements), as well as by the feasibility requirement. Given such a structure, the intermediaries obtains the optimal choice for $l_{t}$ by solving the following problem:

$$
\max _{l, d} \pi_{B t}=i_{l t} l_{t}-i_{d t} d_{t}
$$

s. to.

$$
\begin{aligned}
m_{2 t}+l_{t} & \leqslant d_{t} \\
m_{2 t} & \geq \gamma_{t} d_{t}
\end{aligned}
$$

where $\pi_{B t}$ is the real profit of the financial intermediary at time $t ; m_{2 t}$ and $l_{t}$ are, in real-terms, the cash reserves held by the bank and the loans made, respectively; and, $\gamma_{t}$ is the reserve-deposit ratio. The reserve 
requirement ratio is the ratio of required reserves (which must be held in form of currency) to deposits.

To gain some economic intuition on the role of reserve requirements, our metric for financial repression, let us consider the solution of the problem for a typical intermediary. Free entry, drives profits to zero and we have:

$$
i_{l t}\left(1-\gamma_{t}\right)-i_{d t}=0
$$

Simplifying, in equilibrium, the following condition must hold

$$
i_{l t}=\frac{i_{d t}}{1-\gamma_{t}}
$$

Reserve requirements, thus, tend to induce a wedge between the interest rate on savings and the lending rate for the financial intermediary.

\section{$2.3 \quad$ Firms}

All firms are identical and produces a single final good using a constant returns to scale, Cobb-Douglas-type, production function, given as follows:

$$
y_{t}=A k_{t}^{\alpha}\left(n_{t} \overline{k_{t}}\right)^{1-\alpha}
$$

where $y_{t}$ is the output; $n_{t}$ is the hours of labor supplied inelastically to production in period $t$; $k_{t}$ is the per-firm capital stock in period $t ; \overline{k_{t}}$ denotes the aggregate capital stock in period $t ; A$ is a positive scalar, and; $0<\alpha<1$, is the elasticity of output with respect to capital. Following, Romer (1986), the aggregate capital stock enters into the production function (15) to account for a positive externality indicating an increase in labor productivity as the society accumulates capital stock. It must be noted that in equilibrium, $k_{t}=\overline{k_{t}}$.

At time $t$ the final good can either be consumed or stored. Firms operate in a competitive environment and maximize profit taking the wage rate, the rental rate on capital and the price of the consumption good as given, besides, $\overline{k_{t}}$. The producers use the available bank loans, $l_{t}$, to purchase capital. This is because a firm starts each period with no cash, since free entry and exit in the perfectly competitive product market washes out all profits. Notice that the production transformation schedule is linear so that the same technology 
applies to both capital formation and the production of consumption goods, and, hence, both investment and consumption goods sell for the same price $p_{t}$.

Formally, the firms face the following problem:

$$
\pi_{F t}=\max _{k_{t}, n_{t}} \sum_{i=0}^{\infty} \rho_{t}\left\{p_{t} A k_{t}^{\alpha}\left(n_{t} \overline{k_{t}}\right)^{1-\alpha}-p_{t} w_{t} n_{t}-i_{l t-1} p_{t-1} l_{t-1}+p_{t} l_{t}-p_{t} i_{k_{t}}-p_{t-1} l_{t-1}\right\}
$$

s. to.

$$
\begin{aligned}
p_{t-1} k_{t} & \leq p_{t-1} l_{t-1} \\
k_{t+1} & \leq\left(1-\delta_{k}\right) k_{t}+i_{k_{t}}
\end{aligned}
$$

where $\pi_{F t}$ is the discounted stream of profits for the typical firm; and, $\rho_{t}$ is the subjective discount factor used by the firms. Note that the loan constraint, equation (16), implies that from the firm's point of view, it may as well be renting the capital from the bank itself. Moreover, the loans are strictly one period loans. Because of these assumptions, as pointed out by Chari et al. (1995), the firm can be seen as facing a static problem. Hence, one of the implications of the equilibrium conditions of this version of the model is that the choice of $\rho_{t}$ is immaterial.

The up-shot of the above static problem of the firm yields the following efficiency conditions:

$$
\begin{aligned}
k_{t} & : \quad A \alpha+\left(1-\delta_{k}\right)=\frac{1+i_{l t-1}}{1+\pi_{t}} \\
\left(n_{t}\right) & : \quad A(1-\alpha) k_{t}=w_{t}
\end{aligned}
$$

Equation (18) suggests that the production firm sets its marginal product of the capital good equal to the real rental, while (19), simply states that the firm hires effective labor up to the point where the marginal product of labor equates the real wage. Note, we are using the fact that in equilibrium: $n_{t}=1$ and $k_{t}=\overline{k_{t}}$ holds.

\subsection{Government and the External Sector}

In this subsection, we describe the activities of an infinitely-lived government. The government purchases $g_{t}$ units of the consumption good and is assumed to costlessly transform these one-for-one into what are 
called "government good". The "government good" is assumed to be useless to the agents. The government finances these purchases by income taxation and printing of fiat money. Formally, the government's budget constraint at date $t$ can be defined as follows:

$$
p_{t} g_{t}=\tau_{t} p_{t} w_{t}+\left[M_{t}-M_{t-1}\right]
$$

where $M_{t}=p_{t}\left(m_{1 t}+m_{2 t}\right)$ : is the total money in circulation in nominal terms. We assume that money evolves according to the policy rule $M_{t}=\left(1+\mu_{t}\right) M_{t-1}$, where $\mu(>0)$ is the money growth rate.

Finally, the balance of payments identity of this economy, assuming that (PPP), i.e., $p=e p^{*}$ holds for all $t$, and that there are no transactions in the capital account, is given by:

$$
x_{t}-c_{t}^{*}=0
$$

where $x_{t}$ is the export. The identity, given by equation (21), implies that the trade surplus $\left(x_{t}-c_{t}^{*}\right)$ has to be equal to zero. Without any loss of generality and maintaining consistency with perpetual growth, the exports of the economy, $x_{t}$, will be assumed to be a fixed fraction, $\varphi$, of the domestic output. Alternatively, (21) becomes:

$$
\varphi y_{t}=c_{t}^{*}
$$

\section{Equilibrium}

A valid perfect-foresight, competitive equilibrium for this economy is a sequence of prices $\left\{p_{t}, e_{t}, i_{d t}, i_{l t}\right\}_{t=0}^{\infty}$, allocations $\left\{c_{t}, c_{t}^{*}, n_{t}, i_{k t}\right\}_{t=0}^{\infty}$, stocks of financial assets $\left\{m_{1 t}, m_{2 t}, d_{t}, f_{t}^{*}, l_{t}\right\}_{t=0}^{\infty}$, exogenous sequences of $\left\{p_{t}^{*}\right\}_{t=0}^{\infty}$, and policy variables $\left\{\tau_{t}, \gamma_{t}, \mu_{t}\right\}_{t=0}^{\infty}$ such that:

- Taking $i_{d t}, \tau_{t}, w_{t}, e_{t}$ and $p_{t}$, the consumer optimally chooses $c_{t+1}, c_{t+1}^{*}, d_{t}, m_{1 t}$ and $f_{t}^{*}$, such that (1) is maximized subject to (2) and (3);

- The stock of financial assets, $m_{2 t}$ and $l_{t}$, solve the bank's date- $t$ profit maximization problem, (9), subject to (10) and (11), given prices and policy variables. 
- The real allocations solve the firm's date- $t$ profit maximization problem, (15), subject to (16) and (17), given prices and policy variables.

- The goods, money, loanable funds, labor and the bond market equilibrium conditions are satisfied for all $t \geq 0$.

- The government budget, equation (20), is balanced on a period-by-period basis.

- The equilibrium condition in the external sector requires, equation (22) to holds, along with the PPP condition being satisfied for all $t \geq 0$.

- $i_{d t}, i_{l t}, d_{t}, m_{1 t}, m_{2 t}, f_{t}^{*}, p_{t}=e_{t}$ and $p_{t}^{*}$ must be positive for all $t \geq 0$.

\section{Currency Substitution and Optimal Policy Decisions}

In this section, we analyze whether higher degree of currency substitution would result in an increase in the degree of financial repression within a specific country. In our case, this implies studying whether the optimal choice of the reserve-deposit ratio $\left(\gamma_{t}\right)$ increases following a decrease in $\lambda$ (the share of domestic currency in composite money). For this purpose, we analyze the behavior of a social planner who maximizes the utility of all consumers, by choosing $\tau_{t}, \gamma_{t}$ and $\mu_{t}$ following changes in $\lambda$, subject to the set of inequality constraints: $0 \leq \tau_{t} \leq 1,0 \leq \gamma_{t} \leq 1$, and $\mu_{t} \geq 0$ and also the government budget constraint, equation (20), evaluated at steady-state. Note for the sake of simplicity, as in Basu (2001), we assume that the social planner follows time invariant policy rules. Hence, $\tau_{t}=\tau, \gamma_{t}=\gamma$ and $\mu_{t}=\mu$.

Using (4), (5), (6), (7), (8), (13), (16), (18) and (19), we obtain the following structure for the social planner's problem:

$$
\begin{aligned}
& \max _{\tau, \mu, \gamma} W= \sum_{t=0}^{\infty} \beta^{t} U\left(c_{t+1}, c_{t+1}^{*}, m_{1 t}, f_{t}^{*}\right) \\
& \max _{\tau, \mu, \gamma} W=\left\{\begin{array}{c}
\frac{\Omega}{1-\beta}+\frac{\beta \log (1+\theta)}{(1-\beta)^{2}}+\frac{\log (1-\tau)}{1-\beta}+\frac{\log \left(w_{o}\right)}{1-\beta}+ \\
\frac{\log \left(\frac{\left.1+(1-\gamma)-1+\frac{(1+\mu)\left(1+A \alpha-\delta_{k}\right)}{1+\theta}\right)}{\left.(1-\gamma)-1+\frac{(1+\mu)\left(1+A \alpha-\delta_{k}\right)}{1+\theta}\right)}\right)\left(1-\psi_{1}-\psi_{2}\right)}{1-\beta}+ \\
\frac{\log \left(\frac{\gamma(1+\theta)}{1+\mu}+(1-\gamma)\left(1+A \alpha-\delta_{k}\right)\right)\left(\psi_{1}+\psi_{2}\right)}{1-\beta}
\end{array}\right\}
\end{aligned}
$$


s. to.

$$
\begin{aligned}
& \text { (i) } \phi=\tau+\frac{\mu(1-\tau)}{1+\mu}\left\{\begin{array}{c}
\frac{\lambda\left(1+\gamma \theta+\mu-\gamma \mu-A \alpha(-1+\gamma)(1+\mu)+(-1+\gamma)(1+\mu) \delta_{k}\right)\left(-1+\psi_{1}+\psi_{2}\right)}{(-1+\gamma)\left(-\theta+\mu+A \alpha(1+\mu)-(1+\mu) \delta_{k}\right)}+ \\
\gamma\left(1-\frac{\left(1+\gamma \theta+\mu-\gamma \mu-A \alpha(-1+\gamma)(1+\mu)+(-1+\gamma)(1+\mu) \delta_{k}\right)\left(-1+\psi_{1}+\psi_{2}\right)}{(-1+\gamma)\left(-\theta+\mu+A \alpha(1+\mu)-(1+\mu) \delta_{k}\right)}\right)
\end{array}\right\} \\
& \text { (ii) } 0 \leq \tau \quad \leq 1 \\
& \text { (iii) } \mu \geq 0 \\
& \text { (iv) } 0 \leq \gamma \leq 1
\end{aligned}
$$

where, $\Omega=\frac{\log \left(\psi_{1}\right) \psi_{1}+((1-\lambda) \log (1-\lambda)+\lambda \log (\lambda))\left(1-\psi_{1}-\psi_{2}\right)+\log \left(\psi_{2}\right) \psi_{2}}{1-\beta}$; and consistency with endogenous growth, which requires all real variables to grow at the same rate $(\theta)$ in steady-state, allows us to use the fact that $w_{t}=(1+\theta)^{t} w_{0}$, with $w_{0}$ being the initial value of the real-wage, and also set: $\phi=\frac{g_{t}}{w_{t}}$. Further, using (18), we obtain $w_{0}=A(1-\alpha) k_{0}$, where $k_{0}$ is the initial level of per-capita capital stock. Without any loss of generality, we normalize $k_{0}$ to unity. $\theta$, in turn, is given by the following expression ${ }^{4}$ :

$$
\theta=\frac{1}{2}\left\{\begin{array}{c}
1+A+\mu+A \alpha \mu-A \tau+A \alpha \tau-\delta_{k}-\mu \delta_{k}-A \gamma \psi_{1}+A \alpha \gamma \psi_{1}+ \\
A \gamma \tau \psi_{1}-A \alpha \gamma \tau \psi_{1}-A \gamma \psi_{2}+A \alpha \gamma \psi_{2}+A \gamma \tau \psi_{2}-A \alpha \gamma \tau \psi_{2}-(\eta)^{\left(\frac{1}{2}\right)}
\end{array}\right\}-1
$$

where $\eta=\left\{\begin{array}{c}4 A(-1+\alpha)(-1+\gamma)(1+\mu)(-1+\tau)\left(1+A \alpha-\delta_{k}\right)\left(\psi_{1}+\psi_{2}\right)+ \\ \left(1+A+\mu+A \alpha \mu-A \tau+A \alpha \tau-(1+\mu) \delta_{k}+A \gamma(-1+\alpha+\tau-\alpha \tau) \psi_{1}-A \gamma \psi_{2}+A \alpha \gamma \psi_{2}+A \gamma \tau \psi_{2}-A \alpha \gamma \tau \psi_{2}\right)^{2}\end{array}\right\}$

The problem of the social planner which comprises of maximizing (24) subject to (25), (26), (27) and (28), is non-linear in $\tau, \mu$ and $\gamma$, and requires numerical values for the parameters of the model to obtain the optimal values of the policy variables. ${ }^{5}$ The parameter values, except for the weights of the utility function $\left(\psi_{1}, \psi_{2}\right.$ and $\left.\left(1-\psi_{1}-\psi_{2}\right)\right)$, has been derived from Zimmermann (1994), Chari et al. (1995), Haslag and Young (1998), Basu (2001) and Holman and Neanidis (2006). Further, given the parameter values, and alternative values for $\psi_{1}$ and $\psi_{2}$ and, hence, (1- $\left.\psi_{1}-\psi_{2}\right)$, we calibrate the values of $A$ required to produce a growth rate of 2 percent ${ }^{6}$. The use of alternative values for the parameters defining the weights of the variables in the utility function is warranted not only since no distinct values for such parameters are available in the literature, but, more importantly, because this allowed us to check how sensitive our results are to the

\footnotetext{
${ }^{4}$ Note $\theta$ is independent of $\lambda$ as the savings decisin of the consumers, $d_{t}$, is free of the currency substitution parameter.

${ }^{5}$ All the calculations were carried out using the NMaximize routine in Mathematica 5.0.

${ }^{6}$ The World Development Indicators (published by the World Bank), suggests that the per-capita world growth rate, in recent times, has tended to vary between 1.5 percent to 2.5 percent. We choose 2 percent, simply as an average of this range.
} 
choice of $\psi_{1}$ and $\psi_{2}$. The chosen and the calibrated parameter values can be categorized into four and are summarized as follows ${ }^{7}$ :

$$
\begin{gathered}
\text { Preference: } \psi_{1}=0.70[0.35], \psi_{2}=0.25(0.10), \lambda=0.80 \text { and } 0.70, \beta=0.98 ; \\
\text { Production: } \alpha=0.40, A=2.94(4.01)[6.27], \delta_{k}=0.10 ; \\
\text { Policy: } \tau=0.20, \mu=0.15, \gamma=0.20 ; \phi=0.33^{8} .
\end{gathered}
$$

In this regard, it is important to point out that, as is often observed with monetary endogenous growth models in an overlapping generations framework, we obtained two steady-state growth paths. ${ }^{9}$ For our analysis, the negative root, as defined by (29), was chosen, since, for the given parameter values, while trying to match a growth rate of 2 percent, the positive root yielded a negative value for $A$, the production scalar. Hence, the positive root for $\theta$ was discarded.

Columns 2, 3 and 4, and 5, 6 and 7 of Table 1 compares the optimal values of the tax-rate $\left(\tau^{*}\right)$, the money growth-rate $\left(\mu^{*}\right)$ and the reserve requirement $\left(\gamma^{*}\right)$ respectively, for an increase in the degree of currency substitution, or more precisely, for a fall in the value of $\lambda$ from 0.80 to 0.70 . Note, we repeat the experiment for alternative values of the parameters defining the weights in the utility function. Specifically, we start off with a case where the weight on domestic consumption $\left(\psi_{1}\right)$ exceeds the weight on the foreign consumption $\left(\psi_{2}\right)$, which, in turn, is greater than the weight on composite money $\left(1-\psi_{1}-\psi_{2}\right)$. In the second scenario, we set $\psi_{2}<\left(1-\psi_{1}-\psi_{2}\right)<\psi_{1}$, implying that the consumer values aggregate money more than the foreign consumption, but not more than domestic consumption. Finally, we look, at a situation where, $\left(1-\psi_{1}-\psi_{2}\right)>\psi_{1}>\psi_{2}$, i.e., composite money is valued more than both domestic and foreign consumption, with the domestic good valued more than the foreign good. Note, we also looked at the above three cases with $\psi_{2}>\psi_{1}$, by switching the weights on $\psi_{1}$ and $\psi_{2}$ used above. Understandably, due to the symmetric nature of the consumer's problem, the corresponding results under the three scenarios, as discussed in Table

\footnotetext{
${ }^{7}$ It must be pointed out that, for the sake of simplicity and without any loss of generality, we have converted the parameter values obtained from the five studies, mentioned above, to their nearest multiple of 5 . As long as the framework is retained, the qualitative results of our analysis continues to hold irrespective of the values chosen for these parameters.

${ }^{8}$ Note this value of $\phi$ ensures a government-size of 20 percent, a figure widely encountered in the literature. See Bhattacharya and Haslag (2001) for further details.

${ }^{9}$ See Espinosa and Yip (1999) for further details.
} 
1 , remained quantitatively unchanged. The results in columns 2,3 and 4 , and 5,6 , and 7 , can be visualized as the changes in optimal policies within an economy for an increase in the degree of currency substitution, under different weights imposed on the arguments of the utility function. Alternatively, the comparisons of the results can also be interpreted as the optimal policy decisions of two different economies having exactly the same parameters, but with the exception of the degree of currency substitution.

\section{[INSERT TABLE 1 HERE]}

As can be seen from Columns 4 and 7 of Table 1, irrespective of the weight assigned by households on domestic consumption, foreign consumption and composite money, under scenarios (i), (ii) and (iii), higher currency substitution, always leads to higher optimal values of the reserve requirement. Moreover, in all these cases, the optimal tax rate falls while the optimal money growth rate increases. Two aspects of the results obtained needs to be stressed: First, the optimal money growth rates, under the different situations, generally tends to be very high. However, such a result is not uncommon in monetary growth models based on an overlapping generations framework. ${ }^{10}$ Second, what is more important for our analysis, is the movements of the optimal policy parameters following changes in the degree of currency substitution, rather than their values per se. Intuitively, the results can be explained as follows: When the government size is relatively big, as under scenarios (i), (ii) and (iii), higher degree of currency substitution results in a fall in the size of the seigniorage tax base, via the money held by the consumers. The welfare maximizing government attempts to restore this reduction in the implicit tax base by increasing the reserve requirements and the money growth rate. With the real interest rate falling and reducing the welfare via the decline in domestic and foreign consumption and also through the fall in the growth rate, the welfare maximizing government reduces the tax rate t maintain growth and welfare. However note, all these policy changes takes place simultaneously to ensure that individual welfare is not only maximized but also that the government budget constraint holds.

To check for the robustness of our results, we decided to reduce the value of $\phi$ to 0.25 , and then to 0.20 , implying government-sizes of 15 percent and 12 percent, respectively. In the first case, we find that higher

\footnotetext{
${ }^{10}$ For example see were also obtained by Freeman (1987) and Gupta (2005, 2006, 2008) and Gupta and Ziramba (2008a, 2009a,b). Also refer to Bhattacharya and Haslag (2001) and Gupta and Ziramba (2008c) for a nice exposition as to how this issue can be handled.
} 
currency substitution now leads to higher financial repression in two of the three scenarios of the weights discussed above, i.e., for $\psi_{2}<\left(1-\psi_{1}-\psi_{2}\right)<\psi_{1}$ and $\left(1-\psi_{1}-\psi_{2}\right)>\psi_{1}>\psi_{2}$ holds i.e., when the size of the monetary base is relatively large (refer to equation (6)). When the government size is reduced further to 12 percent of GDP, currency substitution and financial repression are positively correlated only when (1- $\psi_{1}$ - $\left.\psi_{2}\right)>\psi_{1}>\psi_{2}$, i.e., only when the size of the money holdings by the consumer is at its highest and so is the decline in the size of the monetary base following currency substitution. So clearly the size of the government matters. The results make sense, as it is quite well-known that smaller governments in need of lesser revenue can afford to rely less on seigniorage, and, hence, requires lesser number of instruments, especially when the size of the monetary base is small. For the relatively smaller government sizes, higher currency substitution, whenever accompanied by higher financial repression, leads to higher money growth rates and lower tax rates as explained above. However, when the implicit tax base is small i.e., in the case when $\psi_{1}>\psi_{2}>\left(1-\psi_{1}-\psi_{2}\right)$ for medium-sized government, and when $\psi_{1}>\psi_{2}>\left(1-\psi_{1}-\psi_{2}\right)$ and $\psi_{2}<\left(1-\psi_{1}\right.$ - $\left.\psi_{2}\right)<\psi_{1}$, the welfare maximizing government responds by increasing the tax rates and reducing reserve requirements and money growth rates for a decrease in $\lambda$.

So, as far as the relationship between currency substitution and financial repression is concerned, we can draw the following conclusions from the results obtained above:

- Higher currency substitution within a particular economy or across two similar economies (differing only in terms of the share of foreign currency in aggregate money), can cause higher degrees of financial repression;

- With bigger sizes of the government, irrespective of how the consumer values domestic and foreign goods and composite money, higher currency substitution always causes higher financial repression;

- With mid-sized governments, higher currency substitution can also cause higher financial repression, but now the consumer has to value composite money more than at least one kind of consumption good;

- With governments of relatively small sizes, higher currency substitution and reserve requirements are positively related only when the consumer puts more weight on composite money relative to both domestic and foreign goods; 
- Finally, as in Holman and Neanidis (2006), under the comparable case of $\psi_{1}>\psi_{2}>\left(1-\psi_{1}-\psi_{2}\right)$, given that money enters our model via the MIU structure rather than a CIA constraint, direct taxation is the dominant and welfare maximizing method of financing given level of government expenditures.

\section{Conclusions and Areas of Further Research}

This paper, using a general equilibrium overlapping generations monetary endogenous growth model of a small open economy, analyzes the relationship between currency substitution and financial repression. Following other studies in the literature, we define financial repression through an obligatory "high" reserve deposit ratio requirement, that the banks in the economy needs to maintain. In other words, this study attempts to assay whether currency substitution can provide a rationale for financial repression. Specifically, we analyze whether the "high" reserve requirements in a small open economy characterized by currency substitution, are a fall out of a welfare maximizing decision of the government, having access to income taxation and seigniorage as sources of revenue.

We find that, higher currency substitution within a particular economy or across two similar economies, differing only in the degrees of currency substitution, can cause higher degrees of financial repression, with the results depending on the size of the government and what weights the consumer assigns to the domestic and foreign goods and the composite money. We find that relatively big-size of the government is both necessary and sufficient to produce higher financial repression following an increase in the degree of currency substitution. For middle-sized government sufficiency requires the consumer to value composite money more than at least one kind of consumption good, while with smaller-sized government, currency substitution and financial repression are positively correlated only when the consumer puts more emphasis on the composite money than consumption of domestic and foreign goods.

A limitation of the existing study, as in Holman and Neanidis (2006), is that it does not endogenize currency substitution. ${ }^{11}$ The fact that, currency substitution, mainly arises due to high inflation, and hence, should be ideally treated as endogenous, has been ignored in this study. In our economic model, it is as if

\footnotetext{
${ }^{11}$ Gupta (2008) and Gupta and Ziramba (2009a) raises similar concerns about studies treating tax evasion as exogenous and analyzing optimal responses of government policies following changes in the exogenous degree of tax evasion.
} 
to say, that high and continuous inflation episodes have resulted in a certain steady-state level of currency substitution for the economy, and, hence, the same can be treated as exogenous. Moreover, endogenizing currency substitution, would not have allowed us to carry out the existing analysis of optimal policy responses, following a change in the share of the foreign currency in aggregate money. Once currency substitution is endogenized, we would, in turn, have to analyze the optimal policy changes following variations in the structural parameters determining the steady-state level of currency substitution, originating from possibly high money growth rates. But then, in a welfare maximizing set-up with a government responding to higher degrees of currency substitution resulting from higher money growth rates, would amount to the government not being able to use money growth rate as an instrument, simply because further changes in the money growth rate would now cause the degree of currency substitution to change again. So, in the context of our current economic environment, the government will now be left with only the reserve requirements and tax rates as its policy instruments. Nevertheless, this could be an interesting extension.

\section{References}

[1] Bacchetta, P., Caminal, R., 1992. Optimal seigniorage and financial liberalization. Journal of International Money and Finance 11, 518-538.

[2] Barro, R. J., 1990. Government spending in a simple model of endogenous growth. Journal of Political Economy 98, 103-125.

[3] Basu, P., 2001. Reserve ratio, seigniorage and growth. Journal of Macroeconomics 23, 397-416.

[4] Bhattacharya, J., Haslag, J. H., 2001. On the use of inflation tax when non-distortionary taxes are available. Review of Economic Dynamics 4, 823-841.

[5] Caprio, G., Honohan, P., Stiglitz, J. E., 2001. Financial liberalization: How far, how fast? Cambridge University Press, Cambridge, UK. 
[6] Chari, V., Rodolfo E. M., Larry E. J., 1995. The growth effects of monetary policy. Quarterly Review, Federal Reserve Bank of Minneapolis 19, 18-32.

[7] Cuikerman, A., Edward, S., Guido, T., 1992. Seigniorage and political instability. American Economic Review 82, 537-555.

[8] Diamond, P. A., 1965. National debt in a neoclassical growth model. American Economic Review 55, 1126-1150.

[9] Di Giorgio, G., 1999. Financial development and reserve requirements. Journal of Banking and Finance 23, 1031-1041.

[10] Drazen, A., 1989. Monetary policy, seigniorage, and capital controls in an open economy. In: de Cecco, M, Giovannini, A. (Eds.), A European central bank? Perspectives on monetary unification after ten years of the EMS. Cambridge University Press, Cambridge, UK.

[11] Espinosa, M., Chong K. Y., 1996. An endogenous growth model of money, banking, and financial repression. Federal Reserve Bank of Atlanta Working Paper, 96-104.

[12] Espinosa, M., Chong K. Y., 1999. Fiscal and monetary policy interactions in an endogenous growth model with financial intermediaries. International Economic Review 40, 595-615.

[13] Giovannini, A., Martha D. M., 1993. Government revenue from financial repression. American Economic Review 83, 953-963.

[14] Gupta, R., 2005. Costly state monitoring and reserve requirements. Annals of Economics and Finance $6,263-288$.

[15] Gupta, R., 2006. Asymmetric information, tax evasion and alternative instruments of government revenue. The ICFAI Journal of Monetary Economics IV, 75-89.

[16] Gupta, R., 2008. Tax evasion and financial repression. Journal of Economics and Business, 60, 517-535.

[17] Gupta, R., Ziramba E. 2008a. Costly tax enforcement and financial repression. Economic Notes, 37, $141-154$. 
[18] Gupta, R., Ziramba E. 2008b. Openness, bureaucratic corruption, and public policy in an endogenous growth model, Department of Economics, University of Pretoria, Working Paper, No. 200817.

[19] Gupta, R., Ziramba E. 2008b. Optimal public policy with endogenous mortality. Department of Economics, University of Pretoria, Working Paper, No. 200829.

[20] Gupta, R., Ziramba E. 2009a. Tax evasion and financial repression: A reconsideration using endogenous growth models. Journal of Economics Studies, Forthcoming.

[21] Gupta, R., Ziramba E. 2009b. Costly tax enforcement and financial repression: A reconsideration using an endogenous growth model. International Business and Economics Research Journal, Forthcoming.

[22] Hall, R. E., 1988. Intertemporal substitution in consumption., Journal of Political Economy 96, 339357.

[23] Haslag, J. H., Scott E. H., 1995. Does it matter how monetary policy is implemented? Journal of Monetary Economics 35, 359-386.

[24] Haslag, J. H., Young, E. R., 1998. Money creation, reserve requirements, and seigniorage. Review of Economic Dynamics 1, 677-698.

[25] Haslag, J. H., Koo, J., 1999. Financial repression, financial development and economic growth. Federal Reserve Bank of Dallas. Working Paper, 99-102.

[26] Holman, J. A., Neanidis K. C., 2006. Financing government expenditure in an open economy. Journal of Economic Dynamics and Control 30, 1315-1337.

[27] Romer, P., 1986. Increasing returns and long-run growth. Journal of Political Economy 94, 1002-1037.

[28] Roubini, N., Sala-i-Martin, X., 1992. Financial repression and economic growth. Journal of Development Economics 39, 5-30.

[29] Roubini, N., Sala-i-Martin, X., 1995. A growth model of inflation, tax Evasion, and financial repression. Journal of Monetary Economics 35, 275-301. 
[30] Zimmermann, C., 1997. Technology innovations and the volatility of output: An international perspective. CREFE Working Paper, 34 . 
Table 1: Optimal Policy Decisions:

\begin{tabular}{|l|ccc|ccc|}
\hline & \multicolumn{3}{|c|}{$\lambda=0.80$} & \multicolumn{3}{|c|}{$\lambda=0.70$} \\
\cline { 2 - 7 } Scenarios & $\tau^{*}$ & $\mu^{*}$ & $\gamma^{*}$ & $\tau^{*}$ & $\mu^{*}$ & $\gamma^{*}$ \\
\hline (i) $\psi_{1}>\psi_{2}>\left(1-\psi_{1}-\psi_{2}\right)$ & 30.52 & 161.06 & 0.01 & 21.50 & 28199.5 & 11.92 \\
(ii) $\psi_{2}<\left(1-\psi_{1}-\psi_{2}\right)<\psi_{1}$ & 2.97 & 33914.90 & 18.76 & 0.0037 & 35226.40 & 23.84 \\
(iii) $\left(1-\psi_{1}-\psi_{2}\right)>\psi_{1}>\psi_{2}$ & 2.30 & 1994.36 & 0.00 & 0.0060 & 76158.30 & 8.36 \\
\hline \hline (iv) $\psi_{1}>\psi_{2}>\left(1-\psi_{1}-\psi_{2}\right)$ & 17.59 & 23172.90 & 4.00 & 22.10 & 5381.94 & 0.26 \\
(v) $\psi_{2}<\left(1-\psi_{1}-\psi_{2}\right)<\psi_{1}$ & 10.26 & 58231.70 & 0.54 & 7.24 & 706723 & 6.44 \\
(vi) $\left(1-\psi_{1}-\psi_{2}\right)>\psi_{1}>\psi_{2}$ & 0.01 & 161.90 & 0.0021 & 0.00 & 338.65 & 0.0073 \\
\hline \hline (vii) $\psi_{1}>\psi_{2}>\left(1-\psi_{1}-\psi_{2}\right)$ & 16.42 & 11941.00 & 0.31 & 17.11 & 11799.70 & 0.00 \\
(viii) $\psi_{2}<\left(1-\psi_{1}-\psi_{2}\right)<\psi_{1}$ & 2.65 & 32235.80 & 2.30 & 6.98 & 141964.00 & 0.00 \\
(ix) $\left(1-\psi_{1}-\psi_{2}\right)>\psi_{1}>\psi_{2}$ & 7.00 & 45.26 & 0.00 & 0.0025 & 118.98 & 0.0081 \\
\hline Note: All values are in percentages. & & & & & \\
\hline
\end{tabular}

